Salikan N. A., K. K Yern, Zain, N. A, M, Isolation of Antibiotic Resistant Bacteria from Rivers in Terengganu, Malaysia. International Journal of Life Sciences and Biotechnology, 2020. 3(2): p. 241- 257.

DOI: $10.38001 / \mathrm{ij} 1 \mathrm{sb} .711948$

\title{
Isolation of Antibiotic Resistant Bacteria from Rivers in Terengganu, Malaysia
}

\author{
Nurul Aqidah Salikan" ${ }^{1}$, Kam Kar Yern $^{1}$ (D) and Nor Azimah Mohd Zain ${ }^{1 *}$ (D)
}

\begin{abstract}
Infectious disease cause by antibiotic resistant bacteria has been more difficult to treat because the ability of these bacteria to avoid the effect of antibiotic medication. Nowadays, water environment especially river has become the reservoir for the dissemination of antibiotic resistant bacteria due to antibiotic contamination derived from human activities. The exposure to antibiotic resistance bacteria in water increase the health risks associated with the waterborne bacteria in animals and humans. Therefore, this study was carried out to investigate the presence of antibiotic resistant bacteria from two rivers; Ibai River and Terengganu River in Terengganu. A total of 24 bacterial strains were isolated from both rivers. Antibiotic susceptibility of the bacteria isolates was assayed according to the Kirby-Bauer disk diffusion method using six types of antibiotics such as ampicillin, rifampicin, gentamicin, tetracycline, ciprofloxacin and chloramphenicol. The results of this study indicate that $100 \%$ of bacterial strains were resistant to at least two antibiotics tested. The multiple antibiotic resistant (MAR) index of these bacteria was calculated and 23 bacterial strains show MAR index of more than $20 \%$. Among the 23 isolates, a total of 10 bacterial strains $(2 \mathrm{~A}, 2 \mathrm{~B}, 2 \mathrm{C}, 2 \mathrm{I}, 3 \mathrm{~A}, 3 \mathrm{~B}, 4 \mathrm{~A}, 4 \mathrm{C}, 4 \mathrm{D}$ and $4 \mathrm{E})$ were successfully identified as Chromobacterium violaceum, Enterobacter tabaci, Bacillus wiedmannii, Acinetobacter baumannii, Klebsiella quasipneumoniae subsp. quasipneumoniae, Chromobacterium aquaticum, Cupriavidus metallidurans, Weeksella massiliensis, Cupriavidus necator and Acinetobacter nosocomialis. The results from this study show that both of the rivers are exposed to high level of antibiotics compound which may lead the bacteria to develop mechanism of antibiotic resistant. This may cause a serious threat to the public health and environment.
\end{abstract}

\author{
ARTICLE HISTORY \\ Received \\ 1 April 2020 \\ Accepted \\ 6 September 2020
}

\section{KEYWORDS}

Antibiotic resistance bacteria, multiple antibiotic resistance, river waters, Terengganu

\section{Introduction}

River is the most vital freshwater resources for the human and its use for various purposes such as agricultural, recreational, and also industrial activity [1]. However, uncontrolled and overuse of antibiotic in clinical setting and also in intensive animal husbandry gives negative impact to the water environment [2]. These occur due to the release of antibiotics compound into the aquatic system through the agricultural runoff or municipal wastewater as the antibiotic is not fully metabolize in the body human and animal treated with antibiotic [3]. The emergence and development of antibiotic resistance gene in bacteria occur due to natural selection cause by the high levels of antibiotics in the environment [4].

\footnotetext{
${ }^{1}$ Department of Biosciences, Faculty of Science 81310 Johor Bahru, Universiti Teknologi Malaysia

*Corresponding Autor: Nor Azimah Mohd Zain, e-mail: norazimah@utm.my
} 
These cause the environment to become the reservoir for propagation and proliferation of antibiotics resistance genes to pathogen through food web and water [5]. As a consequence, the probability of becoming exposed to antibiotic resistant bacteria outside clinical setting increases [6]. For instance, people may become exposed through the preparation and consumption of contaminated food or ingestion of contaminated water. As a result, cases that involve the antibiotic resistance by organism elevated and become a threat to public life. This definitely become a threat to human health as antibiotic resistant bacteria will cause serious infection especially in debilitated patients which may therefore difficult to treat.

Different defense mechanisms have been developed by bacteria to evade themselves from the effect of antibiotics that was used against them. The genes encoding these defense mechanisms are located on the chromosome of bacteria or on extrachromosomal plasmids and are transmitted to the next generation and these known as vertical gene transfer. Meanwhile, horizontal gene transfer is plasmids that exchanged among bacteria of different taxonomic affiliation. Horizontal gene transfer by conjugation is common in nature because there will be more interaction between bacteria especially when the density of bacteria is high [7].

These environmental antibiotics resistance gene could be a reservoir and horizontally transferred to human-associated bacteria and thus contribute to antibiotic resistance proliferation. Antibiotics exert a selection in favor of resistant bacteria by killing or inhibiting growth of susceptible bacteria; resistant bacteria can adapt to environmental conditions and serve as vectors for the spread of antibiotic resistance depending on their concentrations [8]. Therefore, uncontrolled use of antibiotics may exert selective pressure and resistant pathogen will encounter more frequently [9]. The main risk for public health is that resistance genes are transferred from environmental bacteria to human pathogen.

Therefore, this study aimed to isolate and identify the prevalence of antibiotic resistance bacteria from Ibai River and Terengganu River in Terengganu through biochemical and molecular tools through comparison with Bergey's Manual of Determinative Bacteriology. The rivers may have become the reservoir for spread of these bacterial genes to the water due to discharge of antibiotics compound from the human activities such as fishery activities. Through this study, the implication of antibacterial resistance organism in the river water and the emergence of antibiotic resistance bacteria were evaluated. The risk of the antimicrobial resistance from river water to the public health and food security were also assessed. 


\section{Material and Methods}

\section{Study site and sampling}

The sampling sites were located at two selected rivers such as Ibai River and Terengganu River in Terengganu (Figure 1). The first sampling site (Point 1) was selected from the Ibai River, was located near to small aquaculture farm and residential area in Kampung Laut, Kuala Ibai at the coordinate of $(5.280724,103.141581)$. Meanwhile, second sampling site (Point 2) was selected near to industrial area, residential area and restaurants in Kuala Ibai, Kuala Terengganu. The samples were collected at the coordinate of $(5.278680,103.168602)$. Meanwhile, another river was selected as Terengganu River which located in Kuala Terengganu. The first sampling site (Point 3) with coordinate at $(5.279265,103.084646)$ was located near large aquaculture farms and residential area in Kampung Selar Beladau. Meanwhile, second sampling site (Point 4) with coordinate at $(5.328204,103.125040)$ was located near large aquaculture farm and construction site in Pulau Duyong.

Water sample was collected from two rivers at two different sampling points into the $500 \mathrm{~mL}$ sterile bottle. All the samples were kept in an ice box to maintain its temperature at $4{ }^{\circ} \mathrm{C}$ while transporting to the laboratory and stored in cold room until further analysis [8].

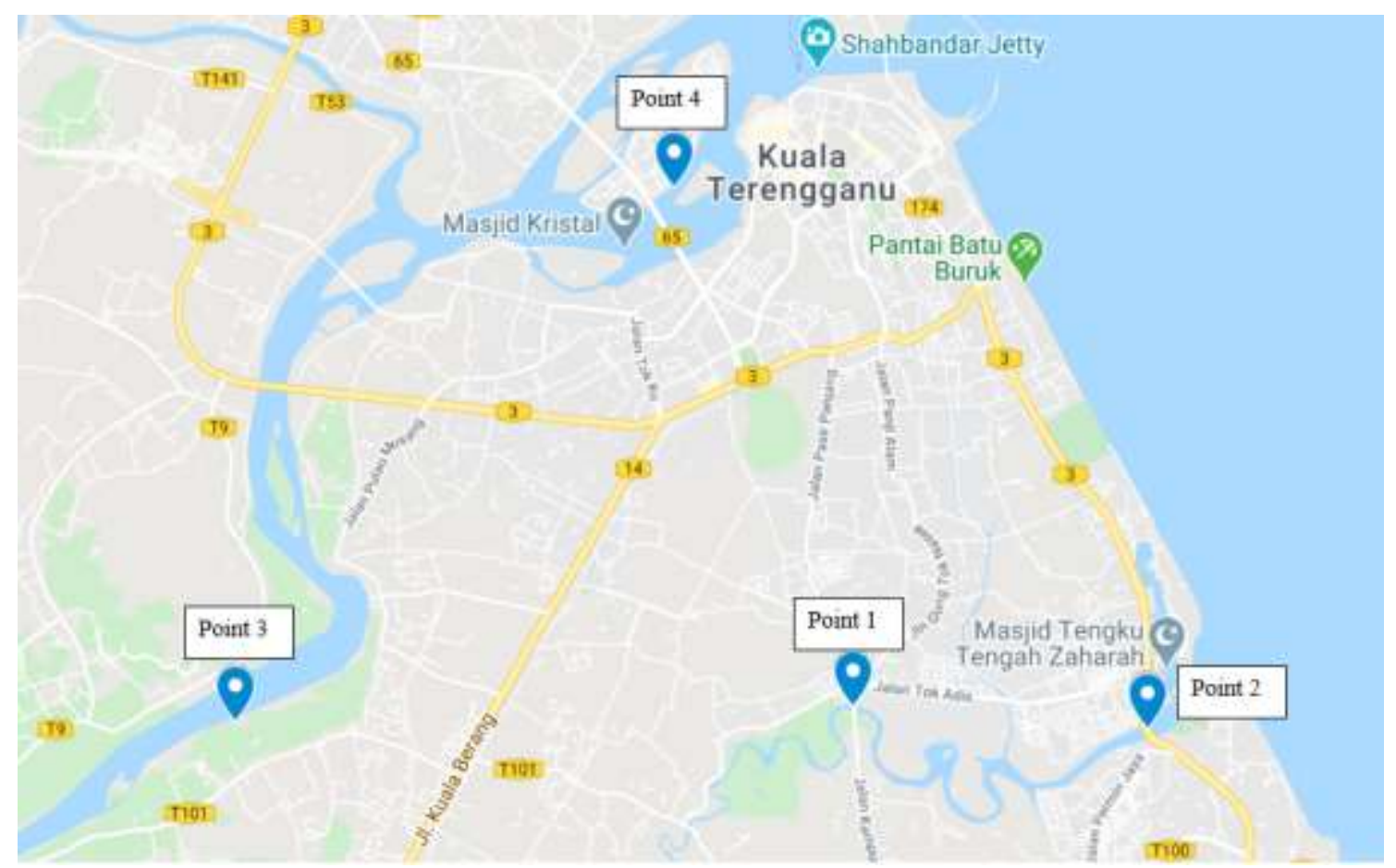

Fig 1 The study map on sampling locations of a) Ibai River (point 1, point 2) and b) Terengganu River (point 3, point 4). 


\section{Isolation of pure bacterial isolates}

In order to isolate the pure bacterial colonies, $1 \mathrm{~mL}$ of each water samples were diluted with 9 $\mathrm{mL}$ of distilled water. Then, the water samples were serially diluted up to 10-4. After that, 100 $\mu \mathrm{L}$ of each dilution was spread on the nutrient agar. The plates were incubated at $37{ }^{\circ} \mathrm{C}$ for 24 hours. The single colonies of different morphology from the spread plates were subculture by streaking method for isolation of pure colonies. The pure colonies of the subculture were characterized based on observation of their morphology. Gram staining was performed to further characterize the pure colonies into Gram-positive bacteria or Gram-negative bacteria [9]

\section{Antibiotic susceptibility testing}

Kirby-Bauer disk diffusion method was used by following the guidelines established by the Clinical and Laboratory Standards Institute (CLSI) to determine the antibiotic susceptibility profile of the bacterial isolates against six types of antibiotics such as gentamicin, ampicillin, rifampicin, chloramphenicol, tetracycline, and ciprofloxacin [10]. The antibiotics that were used in this study are broad spectrum antibiotics that could act against larger group of bacteria including Gram-negative and Gram-positive bacteria [12]. Broad spectrum antibiotics are normally used in treatment of community- or hospital-acquired infections [13]. Bacterial inoculum was prepared by transferring the bacteria into $5 \mathrm{~mL}$ of sterile nutrient broth. The turbidity of the suspension was adjusted to 0.5 McFarland standards. Then, the bacterial isolate in the nutrient broth was inoculated on Mueller-Hinton agar by spreading it using sterile cotton swab. The plates were seeded uniformly by rubbing the swab on the entire agar surface and then incubated for 24 hours [6]. After dried, antibiotic impregnated discs were placed using sterile forceps with appropriate distance; $30 \mathrm{~mm}$ apart and $10 \mathrm{~mm}$ away from the edge of the agar plate with bacterial cultures on it. Each of the antibiotics disc have two different concentrations which are 10 and $30 \mu \mathrm{g} / \mathrm{mL}$. Then, all the plates were incubated at $37^{\circ} \mathrm{C}$ for 24 hours. After overnight incubation, zone of inhibition around each disc was measured based on the interpretive standard of the CLSI used to define the bacterial isolates as sensitive, intermediate or resistant to the antibiotic evaluated.

\section{Multiple Antibiotic Resistant (MAR) Index Value}

The multiple antibiotic resistant (MAR) index for each bacterial isolate against the antibiotics tested were calculated using the formula. Multiple antibiotic resistance index is calculated by the ratio of number of resistant antibiotics to which isolate is resistance to total number of antibiotics to which organism is tested [14]. MAR index is a tool that helps in analyzing health risk which value equal or lower than 0.20 indicate low dose of antibiotic used while 
value more than 0.20 indicates high dose of antibiotic used [10]. Bacteria with MAR index of more than $20 \%$ were selected for further analysis. Equation (1) explains the formula used to calculate the Multiple Antibiotics Resistant (MAR) index of bacteria. Number of antibiotics to which the bacteria is resistance (a) has to be divided by total number of antibiotics tested to bacteria (b) to get value of MAR index [11].

MAR Index value =a/bX100 (Equation 1)

\section{Characterization of the bacterial isolates by biochemical test}

The bacterial isolates were further characterized by biochemical test as the bacteria have different physiology from one species to another. The biochemical tests were performed using the catalase test, indole test, Mac Conkey agar, urease test, mannitol salt agar, citrate test and oxidase test. The biochemical test results were compared with Bergey's Manual of Determinative Bacteriology to predict the possible bacteria species based on their biochemical activities.

\section{Results and Discussion}

\section{Isolation and Characterization of Bacterial Strain from Both Rivers Water Samples}

Total of 24 bacterial colonies were successfully isolated from the water samples of the two rivers. The pure colonies of the subculture were characterized based on observation of their morphology. From Ibai River, 4 colonies were isolated from upstream (Point 1) and 9 colonies were isolated from downstream (Point 2). Meanwhile, a total of 6 colonies were isolated from upstream (Point 3) and 5 colonies were isolated from downstream (Point 4) in Terengganu River. Table 1 shows the morphology characteristics of the bacterial colonies isolated from Ibai and Terengganu rivers. Table 2 shows the bacterial colonies isolated from both Ibai and Terengganu rivers with the Gram stains viewed under 100X magnification.

River is required in almost all the activities of mankind such as agricultural, recreational, irrigation and industrial purposes. However, water quality in many large rivers in many countries has been deteriorated significantly due to anthropogenic activities in the past few decades [15]. 
Table 1 The morphology characteristics of the bacterial colonies isolated from Ibai and Terengganu rivers

\begin{tabular}{|c|c|c|c|c|c|c|c|c|c|c|c|}
\hline \multicolumn{6}{|c|}{ Ibai River } & \multicolumn{6}{|c|}{ Terengganu River } \\
\hline & Opacity & Form & Elevation & Surface & Color & & Opacity & Form & Elevation & Surface & Color \\
\hline \multicolumn{6}{|c|}{ Point 1} & \multicolumn{6}{|c|}{ Point 3} \\
\hline $1 \mathrm{~A}$ & Translucent & Circular & Umbonate & Rough & Pinkish & $3 \mathrm{~A}$ & Translucent & Circular & Raised & Smooth, glistening & White \\
\hline $1 \mathrm{~B}$ & Translucent & Circular & Convex & Smooth, glistening & Whitish & $3 \mathrm{~B}$ & Translucent & Circular & Convex & Rough & Pinkish \\
\hline $1 \mathrm{C}$ & Opaque & Circular & Flat & Smooth, & White & $3 \mathrm{C}$ & Translucent & Circular & Convex & Smooth, glistening & Yellowish \\
\hline $1 \mathrm{D}$ & Opaque & Circular & Flat & Smooth, & Blue-black & $3 \mathrm{D}$ & Translucent & Circular & Convex & Smooth, glistening & Pinkish \\
\hline \multicolumn{6}{|c|}{ Point 2} & $3 \mathrm{E}$ & Translucent & Circular & Raised & Smooth, glistening & Whitish \\
\hline $2 \mathrm{~A}$ & Opaque & Circular & Flat & Smooth & Blue-black & $3 \mathrm{~F}$ & Translucent & Circular & Flat & Smooth & Color of agar \\
\hline 2B & Translucent & Circular & Raised & Smooth, glistening & Whitish & \multicolumn{6}{|c|}{ Point 4} \\
\hline $2 \mathrm{C}$ & Opaque & Irregular & Flat & Smooth & White & $4 \mathrm{~A}$ & Translucent & Circular & Raised & Smooth & Color of agar \\
\hline $2 \mathrm{D}$ & Translucent & Circular & Raised & Smooth, glistening & Yellowish & $4 \mathrm{~B}$ & Opaque & Circular & Umbonate & Rough & White \\
\hline $2 \mathrm{E}$ & Translucent & Circular & Convex & Smooth, glistening & $\begin{array}{c}\text { Color of } \\
\text { agar }\end{array}$ & $4 \mathrm{C}$ & Translucent & Circular & Raised & Smooth, glistening & Yellowish \\
\hline $2 \mathrm{~F}$ & Translucent & Irregular & Flat & Smooth & Whitish & $4 \mathrm{D}$ & Translucent & Circular & Raised & Smooth, glistening & Pinkish \\
\hline & & & & & & $4 \mathrm{E}$ & Translucent & Circular & Flat & Smooth, glistening & Color of agar \\
\hline
\end{tabular}


Table 2 The bacterial colonies isolated from both Ibai and Terengganu rivers with the Gram stains viewed under 100X magnification

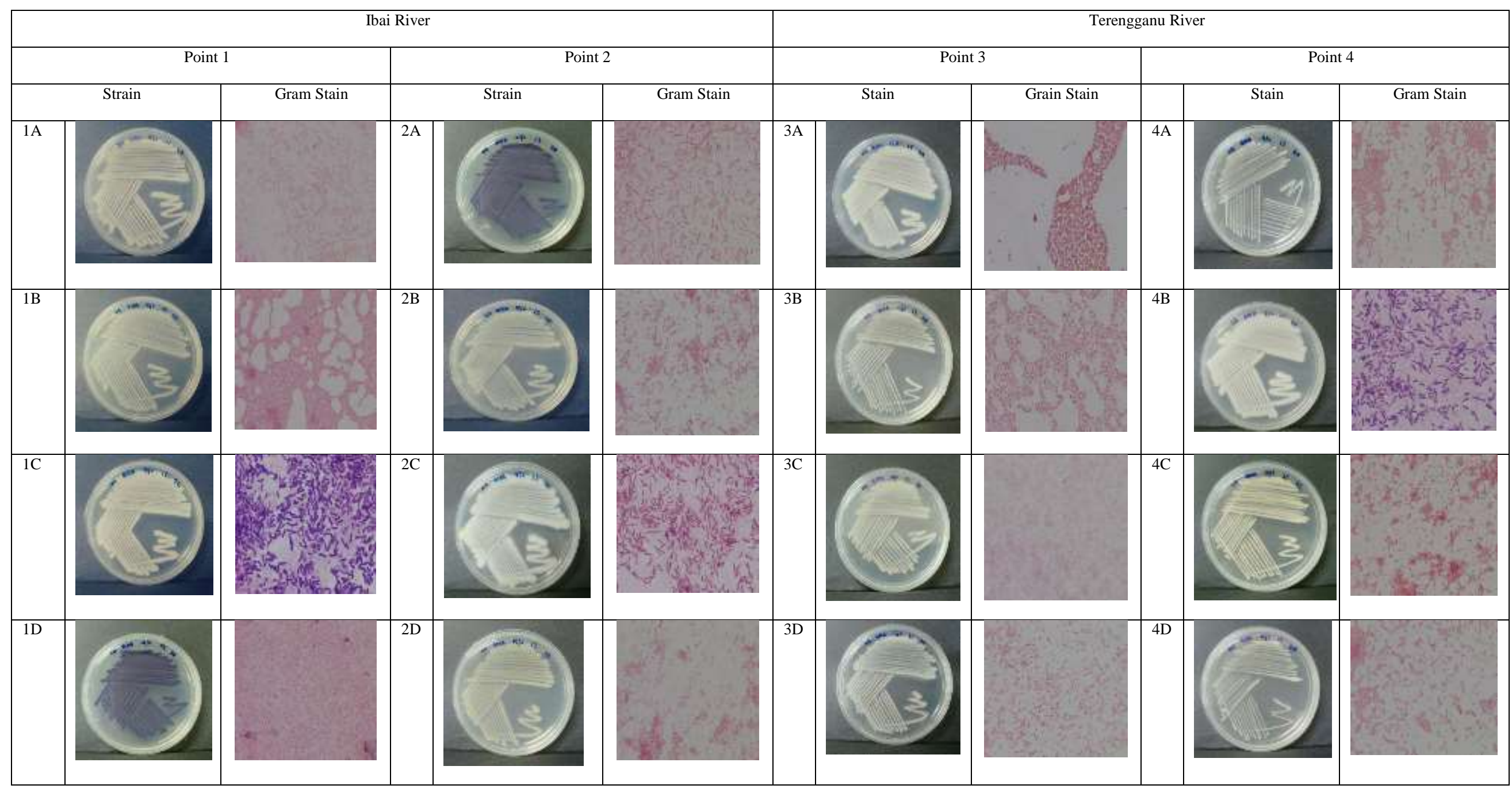




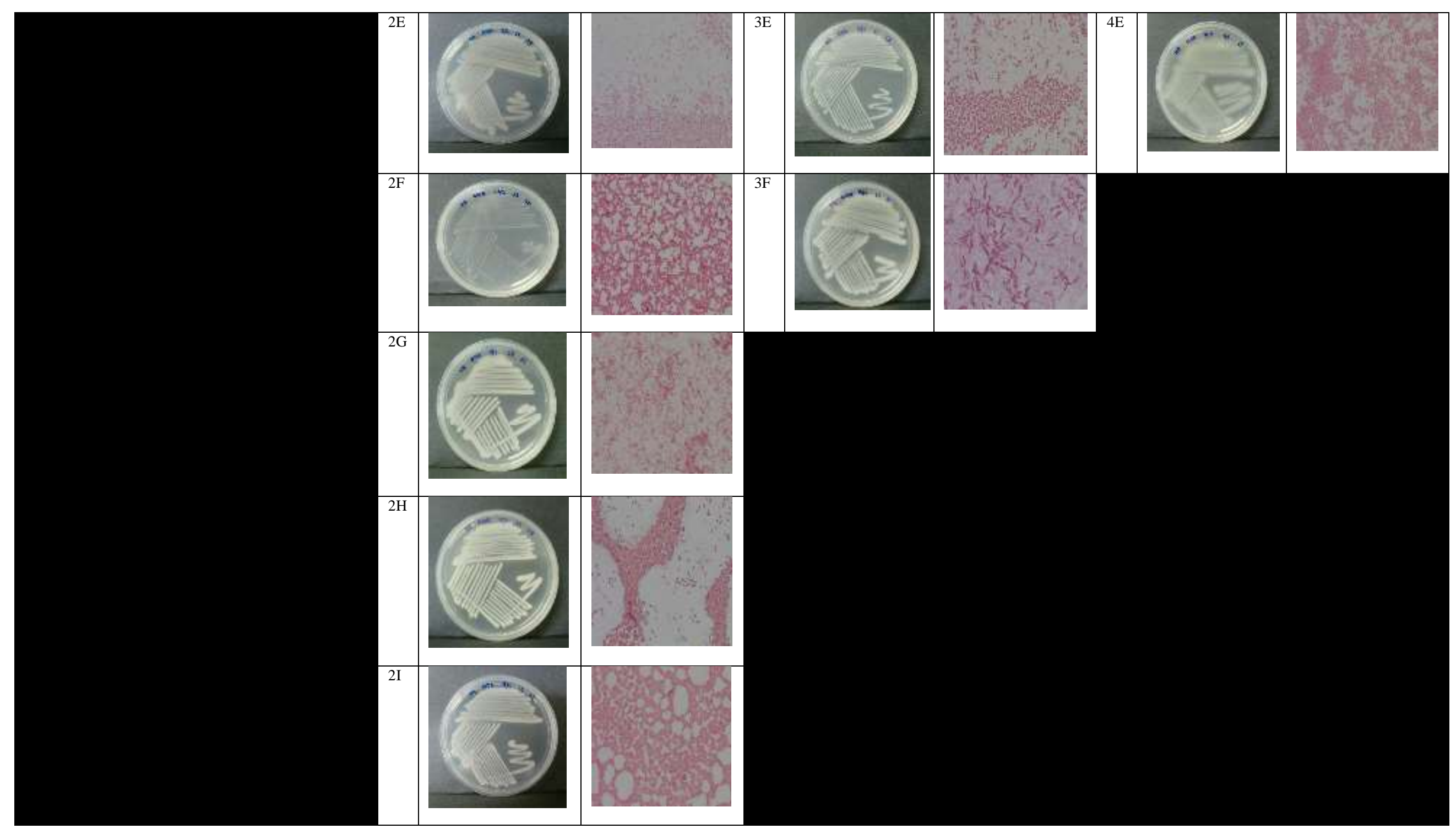




\section{Antibiotic Susceptibility Testing}

The result from the antibiotic susceptibility test in Table 3 and Table 4 shows that all the isolated bacteria were multiple antibiotic resistant (MAR). All of the isolated bacteria show resistant to at least two antibiotics tested. The isolated bacteria were tested against both 10 $\mu \mathrm{g} / \mathrm{ml}$ and $30 \mu \mathrm{g} / \mathrm{ml}$ concentration of all antibiotics tested, in which many of the bacterial isolates were resistant towards both concentration of antibiotics tested. Most of the bacterial isolates were highly resistant towards ampicillin, rifampicin, gentamicin, tetracycline and chloramphenicol. Meanwhile, only one isolated bacteria in Terengganu River was resistant towards both concentration of ciprofloxacin used. Furthermore, bacterial isolates from Ibai River shows no resistant towards ciprofloxacin at both concentrations tested. Low or no resistance of bacteria towards ciprofloxacin may indicate that both rivers were contaminated with low level of ciprofloxacin. There may be low use of ciprofloxacin from the human activities in that area [16].

The discharge of municipal and industrial wastewater to the river water may cause to the presence of antibiotic residual and antibiotic contamination in the river water $[17,18]$. This may lead to the emergence and development of antibiotic resistant bacteria in river water. Therefore, in this study two rivers water in Terengganu which were Ibai River and Terengganu River were selected to study for the correlation between the anthropogenic activities nearby with the emergence of antibiotic resistant bacteria. In Terengganu, river plays as important asset for the economic resources especially in Terengganu River where there were many large aquaculture farms across the river owned by the resident as their source of income. Aquaculture surrounding environment may also become the cause of antibiotic pollution in river water [19]. Besides, Terengganu River located near to the construction site and residential area. It was selected because the location was in the area influenced by the construction site of drawbridge of Terengganu and large aquaculture farms as well as residential area. Meanwhile, Ibai River was located in Kuala Ibai, a densely populated area. It was selected because the location was in the urban area that affected by the residential area, industrial activities and aquaculture farm. Moreover, Ibai river also is connected with small rivers which cause the flows of water from other location. There is also a small aquaculture farm own by the resident at the upstream of this river. 
Table 3 Antibiotic susceptibility tests for the bacterial colonies isolated from Point 1 and Point 2 at Ibai River.

\begin{tabular}{|c|c|c|c|c|c|c|c|c|c|c|c|c|c|c|}
\hline & & Antibiotics & Gen & micin & & cillin & & picin & Chlora & henicol & Tetr & ycline & Cip & oxacin \\
\hline & & $\begin{array}{l}\text { Bacterial } \\
\text { Colonies }\end{array}$ & $\begin{array}{c}10 \\
\mu \mathrm{g} / \mathrm{ml}\end{array}$ & $\begin{array}{c}30 \\
\mu \mathrm{g} / \mathrm{ml}\end{array}$ & $\begin{array}{c}10 \\
\mu \mathrm{g} / \mathrm{ml}\end{array}$ & $\begin{array}{c}30 \\
\mu \mathrm{g} / \mathrm{ml}\end{array}$ & $\begin{array}{c}10 \\
\mu \mathrm{g} / \mathrm{ml}\end{array}$ & $\begin{array}{c}30 \\
\mu \mathrm{g} / \mathrm{ml}\end{array}$ & $\begin{array}{c}10 \\
\mu \mathrm{g} / \mathrm{ml}\end{array}$ & $\begin{array}{c}30 \\
\mu \mathrm{g} / \mathrm{ml}\end{array}$ & $\begin{array}{c}10 \\
\mu \mathrm{g} / \mathrm{ml}\end{array}$ & $\begin{array}{c}30 \\
\mu \mathrm{g} / \mathrm{ml}\end{array}$ & $\begin{array}{r}10 \\
\mu \mathrm{g} / \mathrm{ml}\end{array}$ & $\begin{array}{r}30 \\
\mu \mathrm{g} / \mathrm{ml}\end{array}$ \\
\hline \multirow[b]{8}{*}{ Ibai } & \multirow{4}{*}{ Point 1} & $1 \mathrm{~A}$ & $\mathrm{R}$ & $\mathrm{R}$ & $\mathrm{R}$ & $\mathrm{R}$ & $\mathrm{R}$ & $\mathrm{R}$ & $\mathrm{R}$ & S & S & $\mathrm{S}$ & $\mathrm{S}$ & S \\
\hline & & 1B & $\mathrm{R}$ & $S$ & $\mathrm{R}$ & $\mathrm{R}$ & $\mathrm{R}$ & $\mathrm{R}$ & $\mathrm{R}$ & $\mathrm{R}$ & $\mathrm{R}$ & $\mathrm{R}$ & $S$ & $S$ \\
\hline & & $1 \mathrm{C}$ & $\mathrm{S}$ & $S$ & $\mathrm{R}$ & $\mathrm{R}$ & $\mathrm{S}$ & $S$ & $\mathrm{R}$ & $\mathrm{R}$ & $\mathrm{R}$ & $\mathrm{S}$ & $S$ & $S$ \\
\hline & & $1 \mathrm{D}$ & $\mathrm{R}$ & $\mathrm{R}$ & $\mathrm{R}$ & $\mathrm{R}$ & $\mathrm{R}$ & $S$ & $S$ & $\mathrm{~S}$ & $S$ & $\mathrm{~S}$ & $S$ & $S$ \\
\hline & \multirow{9}{*}{ Point 2} & $2 \mathrm{~A}$ & $\mathrm{R}$ & $\mathrm{S}$ & $\mathrm{R}$ & $\bar{R}$ & $\mathrm{R}$ & $S$ & $S$ & $S$ & $S$ & $\bar{R}$ & $S$ & $S$ \\
\hline & & 2B & $\mathrm{R}$ & $\mathrm{R}$ & $\mathrm{R}$ & $\mathrm{R}$ & $\mathrm{R}$ & $\mathrm{R}$ & $\mathrm{R}$ & $\mathrm{R}$ & $\mathrm{R}$ & $\mathrm{S}$ & $\mathrm{S}$ & $\mathrm{S}$ \\
\hline & & $2 \mathrm{C}$ & $S$ & $S$ & $\mathrm{R}$ & $\mathrm{R}$ & $S$ & $S$ & $\mathrm{R}$ & $\mathrm{R}$ & $S$ & $\mathrm{~S}$ & $S$ & $S$ \\
\hline & & $2 \mathrm{D}$ & $\mathrm{R}$ & $S$ & $\mathrm{R}$ & $\mathrm{R}$ & $\mathrm{R}$ & $\mathrm{R}$ & $\mathrm{R}$ & $\mathrm{R}$ & $\mathrm{R}$ & $\mathrm{R}$ & $\mathrm{S}$ & $\mathrm{S}$ \\
\hline \multirow[t]{5}{*}{ River } & & $2 \mathrm{E}$ & $\mathrm{R}$ & $\mathrm{S}$ & $\mathrm{R}$ & $\mathrm{R}$ & $\mathrm{R}$ & $\mathrm{R}$ & $\mathrm{R}$ & $S$ & $\mathrm{R}$ & $\mathrm{S}$ & $S$ & $S$ \\
\hline & & $2 \mathrm{~F}$ & $\mathrm{~S}$ & $\mathrm{~S}$ & $\mathrm{~S}$ & $\mathrm{~S}$ & $\mathrm{R}$ & $\mathrm{R}$ & $\mathrm{R}$ & $\mathrm{R}$ & $\mathrm{R}$ & S & S & S \\
\hline & & $2 \mathrm{G}$ & $\mathrm{R}$ & $\mathrm{R}$ & $\mathrm{R}$ & $\mathrm{R}$ & $\mathrm{R}$ & $\mathrm{R}$ & $\mathrm{R}$ & $\mathrm{R}$ & $\mathrm{R}$ & $\mathrm{S}$ & $\mathrm{S}$ & $\mathrm{S}$ \\
\hline & & $2 \mathrm{H}$ & $\mathrm{S}$ & $\mathrm{S}$ & $\mathrm{R}$ & $\mathrm{R}$ & $\mathrm{R}$ & $\mathrm{R}$ & $\mathrm{R}$ & $\mathrm{R}$ & $\mathrm{R}$ & $\mathrm{R}$ & $S$ & $S$ \\
\hline & & 2I & $\mathrm{R}$ & $S$ & $\mathrm{R}$ & $\mathrm{R}$ & $\mathrm{R}$ & $\mathrm{R}$ & $\mathrm{R}$ & $S$ & $\mathrm{R}$ & $\mathrm{S}$ & $\mathrm{S}$ & $\mathrm{S}$ \\
\hline
\end{tabular}


Table 4 Antibiotic susceptibility test for the bacterial colonies isolated from Point 3 and Point 4 at Terengganu River.

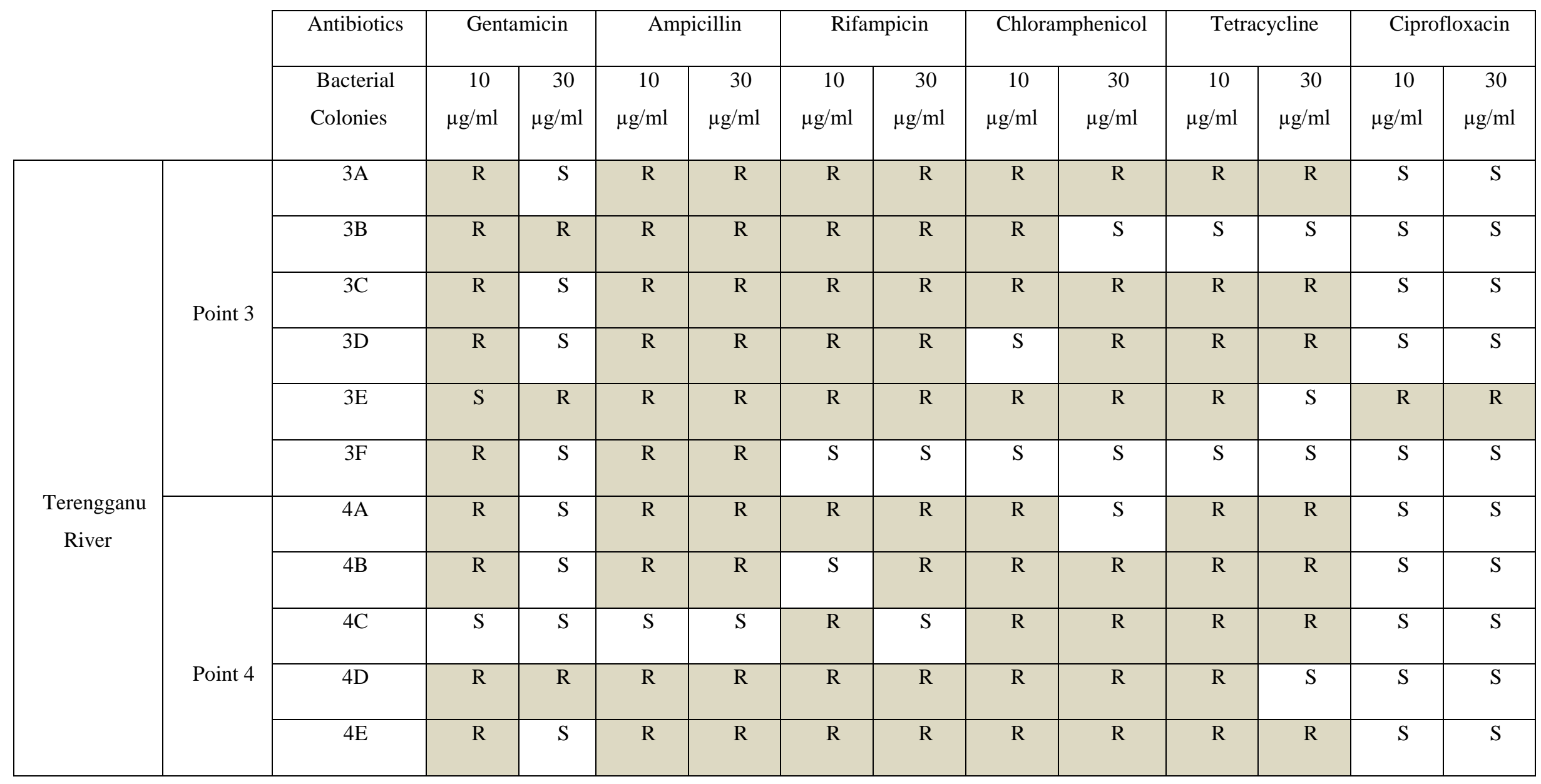




\section{MAR Index Analysis}

From the Figure 2 (a), a total of 13 isolates from Ibai River shows MAR Index more that 20\%. Meanwhile for Terengganu River, 10 out of 11 isolates shows MAR Index more that $20 \%$. Based on the results, all the bacterial isolates were multiple antibiotic resistant (MAR) as it resistant to at least two antibiotics. MAR index with value more than 0.2 indicate a 'highrisk' source of antibiotic contamination [20]. The location was in the urban area that affected by the residential area, industrial activities and aquaculture farm. Besides, Ibai River also is connected with small rivers which cause the flows of water from other location. There is also a small aquaculture farm own by the resident at the upstream of this river. In this study, the samples obtained from Terengganu River were collected near to an aquaculture farm, industrial area, near to construction site area and also from the location that were close to the residential area. These findings show clear evidence of antibiotic resistant bacteria emergence at the sampling locations.

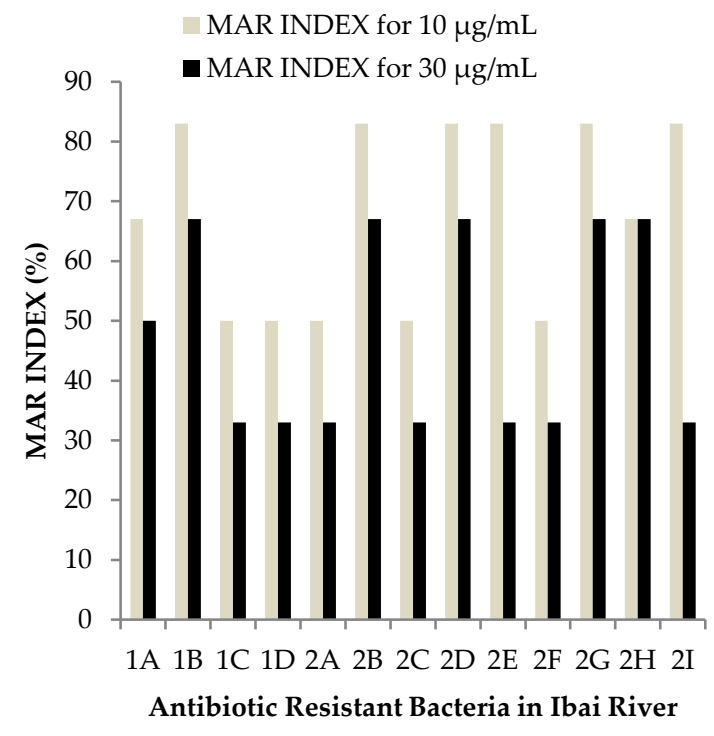

a)

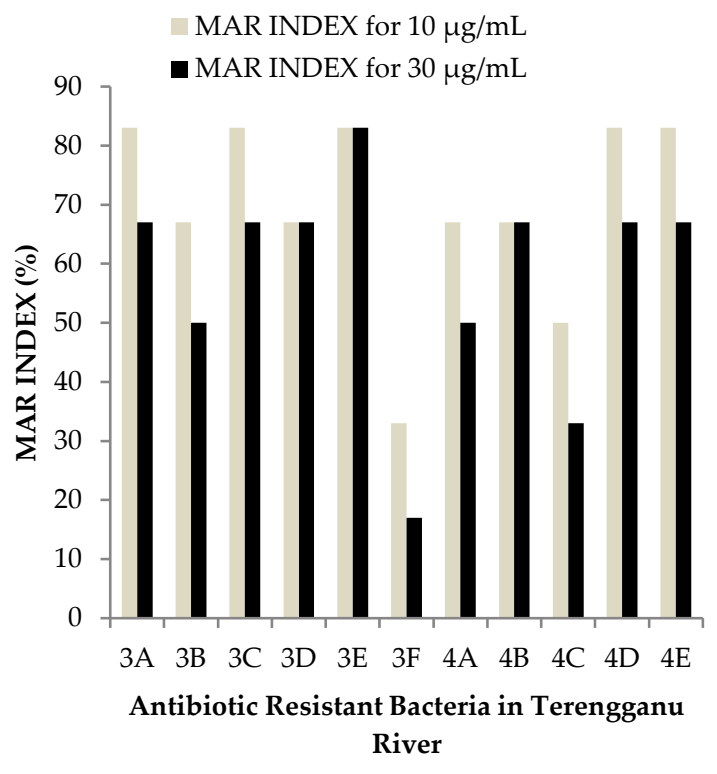

b)

Fig 2 MAR Index for bacteria isolated from a) Ibai River and b) Terengganu River.

\section{Biochemical Test}

Table 5 tabulates the biochemical tests were conducted for all the isolates collected from Ibai and Terengganu rivers. Based on the table, it can be concluded that the different in bacterial population for different point in the same river may be due to the human activities around the sampling areas. From the result of Gram staining, there were 2 out of 24 bacterial colonies 
$(8.33 \%)$ were Gram-positive with rod shape. Meanwhile, 9 bacterial colonies (37.5\%) were Gram-negative bacteria with cocci shape and 13 bacterial colonies (54.2\%) were Grampositive bacteria with rod shape. This meant that, most of the isolated bacterial were Gramnegative bacteria. The $\mathrm{pH}$ of both river water which has slightly acidic; range from $\mathrm{pH} 5$ to 6 favor for the Gram-negative bacteria. In Point 1, with total of 4 bacterial colonies, one of them was Gram-positive bacteria with rod shape, 2 colonies were Gram-negative bacteria with rod shape and the rest was Gram-negative bacteria with cocci shape. Meanwhile in Point 2, all the bacterial isolates were Gram-negative bacteria with 5 colonies were rod shape and 4 colonies were cocci shape. The same to Point 3, most of the bacterial isolates also were Gram-negative bacteria with 4 colonies were rod shape and 2 colonies were cocci shape. From Point 4 , one of the bacterial isolates was Gram-positive bacteria with rod shape. The rest of the bacterial isolates were Gram-negative bacteria with 2 colonies were rod shape and 2 colonies were cocci. 
Table 5 Biochemical tests conducted for isolates from Ibai River and Terengganu River.

\begin{tabular}{|c|c|c|c|c|c|c|c|c|c|c|c|c|c|c|c|c|c|c|c|c|c|c|c|c|c|c|c|c|c|c|c|c|c|c|c|}
\hline \multicolumn{18}{|c|}{ Ibai River } & \multicolumn{18}{|c|}{ Terengganu River } \\
\hline \multicolumn{9}{|c|}{ Point 1} & \multicolumn{9}{|c|}{ Point 2} & \multicolumn{9}{|c|}{ Point 3} & \multicolumn{9}{|c|}{ Point 4} \\
\hline & \multicolumn{7}{|c|}{ Biochemical Test } & & \multicolumn{8}{|c|}{ Biochemical Test } & & \multicolumn{8}{|c|}{ Biochemical Test } & & \multicolumn{8}{|c|}{ Biochemical Test } & \multirow[b]{2}{*}{$\begin{array}{l}\text { Conclusion } \\
\text { (Family } \\
\text { Type) }\end{array}$} \\
\hline 墕 & 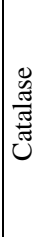 & 苞 & 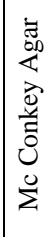 & $\overrightarrow{0}$ & 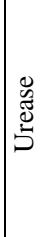 & 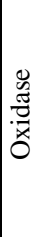 & 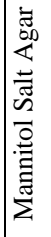 & $\begin{array}{l}\text { Conclusion } \\
\text { (Family Type) }\end{array}$ & 竝 & 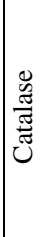 & 苞 & 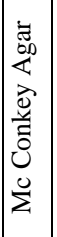 & $\overrightarrow{0}$ & 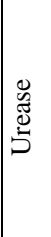 & 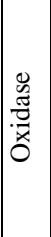 & 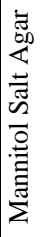 & $\begin{array}{l}\text { Conclusion } \\
\text { (Family Type) }\end{array}$ & 苞 & 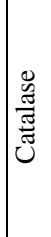 & 节 & 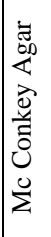 & 鄫 & 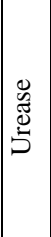 & 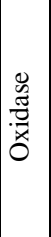 & 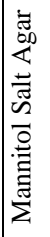 & $\begin{array}{l}\text { Conclusion } \\
\text { (Family Type) }\end{array}$ & 节 & 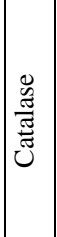 & 节 & 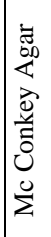 & 客 & 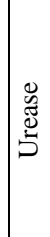 & 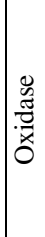 & 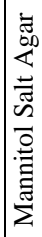 & \\
\hline$\unlhd$ & - & + & - & - & - & + & - & $\begin{array}{l}\text { Vibrio sp. } \\
\text { Enterobacter } \\
\text { sp. } \\
\text { Pseudomonas } \\
\text { sp. }\end{array}$ & 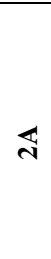 & + & - & - & - & - & - & - & $\begin{array}{l}\text { Enterobacter } \\
\text { sp. } \\
\text { Salmonella sp. } \\
\text { Pseudomonas } \\
\text { sp. }\end{array}$ & $\overleftrightarrow{m}$ & + & + & + & - & + & - & + & $\begin{array}{l}\text { Klebsiella sp. } \\
\text { Enterobacter } \\
\quad \text { sp. } \\
\text { Salmonella sp. }\end{array}$ & 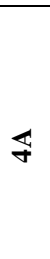 & + & + & - & - & - & + & - & $\begin{array}{l}\text { Vibrio sp. } \\
\text { Pseudomon } \\
\text { as sp. } \\
\text { Proteus sp. }\end{array}$ \\
\hline$\cong$ & + & + & + & - & + & + & + & $\begin{array}{c}\begin{array}{c}\text { Pseudomonas } \\
\text { sp. }\end{array} \\
\text { Vibrio sp. } \\
\text { Proteus sp. }\end{array}$ & สิ & + & + & + & - & - & - & + & $\begin{array}{c}\text { Proteus sp. } \\
\text { Salmonella sp. } \\
\text { Vibrio } \text { sp. }\end{array}$ & लै & - & + & - & - & - & + & - & $\begin{array}{c}\text { Vibrio sp. } \\
\text { Pseudomonas } \\
\text { sp. } \\
\text { Proteus sp. }\end{array}$ & $\vartheta$ & + & - & - & - & - & - & - & $\begin{array}{l}\text { Staphylococ } \\
\text { cus } \mathrm{sp} . \\
\text { Bacillus } \mathrm{sp} .\end{array}$ \\
\hline$\underline{U}$ & + & - & - & - & + & + & - & $\begin{array}{c}\text { Bacillus sp. } \\
\text { Staphylococcu } \\
\text { s sp. }\end{array}$ & U & + & - & + & - & + & + & - & $\begin{array}{l}\text { Proteus sp. } \\
\text { Pseudomonas } \\
\text { sp. } \\
\text { Klebsiella sp. }\end{array}$ & U్ల & - & - & - & - & - & - & - & $\begin{array}{l}\text { Enterobacter } \\
\text { sp. } \\
\text { Proteus sp. } \\
\text { Pseudomonas } \\
\text { sp. }\end{array}$ & U & + & - & - & + & - & + & - & $\begin{array}{c}\text { Pseudomon } \\
\text { as } \mathrm{sp} . \\
\text { Enterobacte } \\
r \mathrm{sp} . \\
\text { Vibrio } \mathrm{sp} .\end{array}$ \\
\hline
\end{tabular}




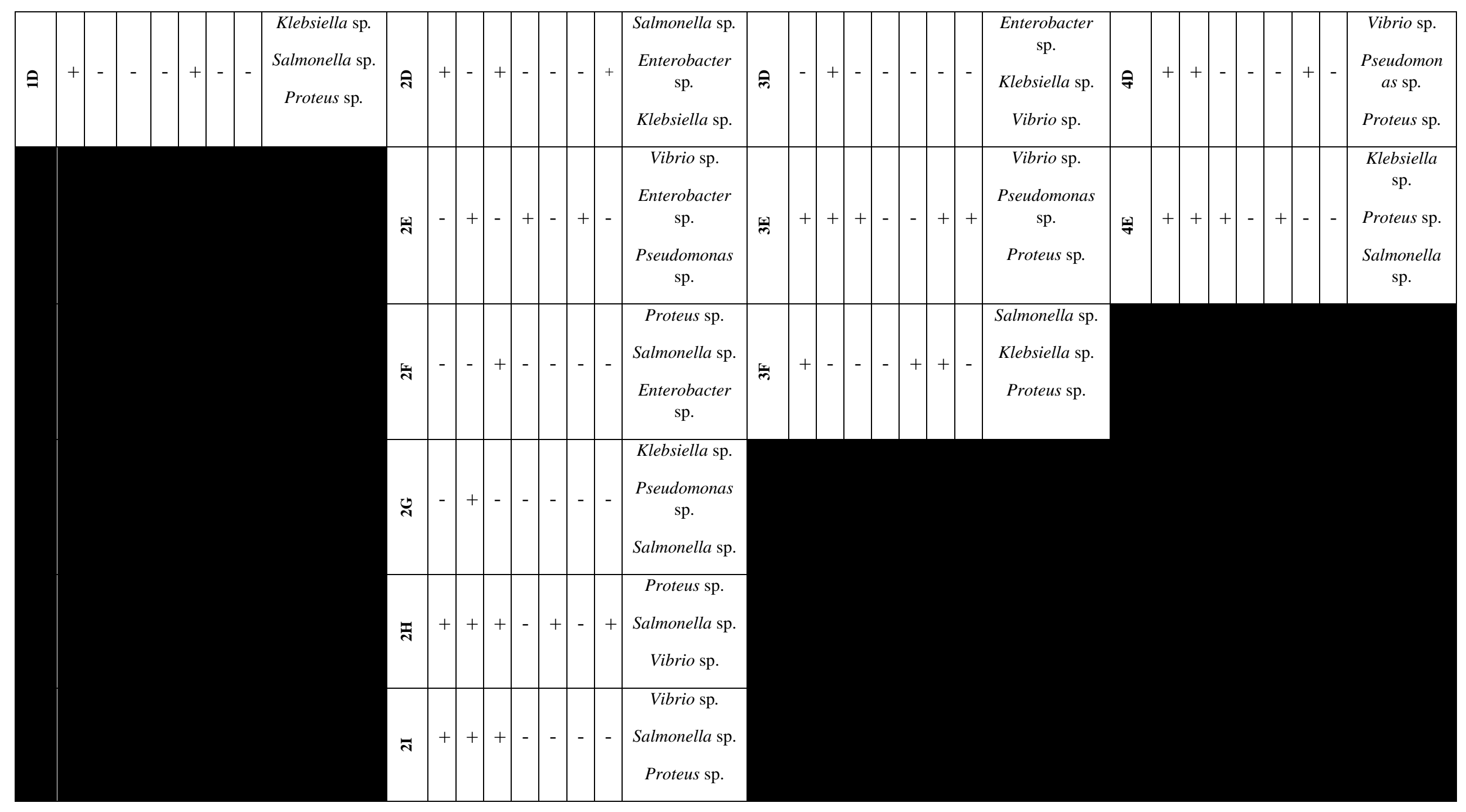




\title{
Conclusion
}

This study showed that a total of 24 pure bacterial colonies were successfully isolated from water samples of two selected rivers which are Ibai River (Point 1: 4 colonies; Point 2: 9 colonies) and Terengganu River (Point 3: 6 colonies; Point 4: 5 colonies) in Terengganu. The bacterial isolates were tested for its susceptibility towards 6 antibiotics; gentamicin, ampicillin, rifampicin, chloramphenicol, tetracycline, and ciprofloxacin. All of the isolates from Ibai River shows MAR index more than 20\%. Meanwhile a total of 10 out of 11 isolates from Terengganu River shows MAR index more than 20\%. The results obtained showed that most of the isolates were multiple antibiotic resistance, indicated that Ibai and Terengganu rivers might consist of 'high-risk' source of antibiotic contamination.

\author{
Abbreviations \\ CLSI: Clinical and Laboratory Standard Institute; MAR: Multiple antibiotics resistance
}

\section{Acknowledgements}

We sincerely thank the staff and administration of the Universiti Teknologi Malaysia for their assistance and support in this study.

\section{Funding}

This study is funded by the Geran Universiti Penyelidikan (GUP) sub vote 17 H74 and UTMShine Grant sub vote 04G97, which is supported by the Universiti Teknologi Malaysia.

\section{Availability of data and material}

Please contact the corresponding author for any data request.

\section{References}

1. Zaideen, I. M. M., S. Suratman, and N. M. Tahir, The Evaluation of Spatial Variation of Water Quality in Sungai Setiu Basin, Terengganu. Sains Malaysiana, 2017. 46(9): p. 1513-1520.

2. Loh, C.M., S. Mamphweli, E. Meyer, and A. Okoh, Antibiotic use in Agriculture and its Consequential Resistance in Environmental Sources: Potential Public Health Implications. Molecules, 2018. 23(4): p. 795.

3. Felis, E., J. Kalka, A. Sochacki, K. Kowalska, S. Bajkacz, M. Harnisz, and E. Korzeniewska, Antimicrobial Pharmaceuticals in the Aquatic Enviornment - Occurrence and Environmental Implications. European Journal of Pharmacology, 2020. 866(2020): p. 172813.

4. Ben, Y., C. Fu, M. Hu, L. Liu, M. H. Wong, and C. Zheng, Human Health Risk Assessment of Antibiotic Resistance Associated with Antibiotic Residues in the Environment: A Review, 2019. 169: p. 483-493.

5. Khan, G. A., et al., Occurrence and abundance of antibiotics and resistance genes in rivers, canal and near drug formulation facilities-a study in Pakistan. PLoS One, 2013. 8(6): e62712.

6. Onuoha, S. C., The Prevalence of Antibiotic Resistant Diarrhogenic Bacterial Species in Surface Waters, South Eastern Nigeria. Ethiopian Journal of Health Sciences, 2017. 27(4): p. 319-330.

7. Schwartz, T., et al., Detection of antibiotic-resistant bacteria and their resistance genes in wastewater, surface water, and drinking water biofilms. FEMS Microbiology Ecology, 2003. 43(3): p. 325-335.

8. Moges, F., et al., Isolation and characterization of multiple drug resistance bacterial pathogens from waste water in hospital and non-hospital environments, Northwest Ethiopia. BMC Research Notes, 2014. 7(1): 215 . 
9. Roy, R. P., M. Bahadur, and S. Barat., Isolation, identification and Antibiotic resistance of Aeromonas spp. and Salmonella spp. from the fresh water loach, Lepidocephalichthys guntea and water of Terai River Lotchka, West Bengal, India. Zoologica Poloniae, 2013. 58(1-2): p. 5-17.

10. Laith, A., and M. Najiah, Aeromonas hydrophila: antimicrobial susceptibility and histopathology of isolates from diseased catfish, Clarias gariepinus (Burchell). Journal of Aquaculture Research and Development, 2013. 5: p. 215.

11. Joseph, A. A., M. S. Odimayo, L. B. Olokoba, A. B. Olokoba, and G. O. Popoola, Multiple Antibiotic Resistance Index of Escherichia coli Isolates in a Tertiary Hospital in South-West Nigeria. Medical Journal of Zambia, 2017. 44(4): p. 225-232.

12. Leekha, S., C. L. Terrell, and R. S. Edson, General Principles of Antimicrobial Therapy. Mayo Clinic Proceedings, 2011. 86(2): p. 156-167.

13. Almulhim, A. S., and F. M. Alotaibi, Comparison of Broad-spectrum Antibiotics and Norrow-spectrum Antibiotics in the Treatment of Lower Extremity Cellulitis. International Journal of Health Sciences, 2018. 12(6): p. 3-7.

14. Osundiya, O., R. Oladele, and O. Oduyebo, Multiple antibiotic resistance (MAR) indices of Pseudomonas and Klebsiella species isolates in Lagos University Teaching Hospital. African Journal of Clinical and Experimental Microbiology, 2013. 14(3): p. 164-168.

15. Gasim, M. B., M. M. Hanafiah, A. Azid, H. M. A. Alssgeer, and E. R. A. Abdulhadi, GIS-based analysis of water quality deterioration in the Nerus River, Kuala Terengganu, Malaysia. Desalination and Water Treatment, 2018. 112(2018): p. 334-343.

16. Odonkor, S. T., and K. K. Addo, Prevalence of multidrug-resistant Escherichia coli isolated from drinking water sources. International Journal of Microbiology, 2018. 2018: p.1-7.

17. Mahmood, A.R., H. H. Al-Haideri, and F. M. Hassan, Detection of Antibiotics in Drinking Water Treatment Plants in Baghdad City, Iraq. Hindawi, 2019. 2019: p. 1- 10.

18. Gao, P., Y. J. Ding, H. Li, and I. Xagoraraki, Occurrence of Pharmaceuticals in a Municipal Wastewater Treatment Plant: Mass Balance and Removal Processes. Chemosphere. 2012. 88(1): p. 17-24.

19. Kathleen, M., et al., Antibiotic resistance of diverse bacteria from aquaculture in Borneo. International Journal of Microbiology, 2016. 2016: p.1-9.

20. Amalina, N. Z., S. Santha, D. Zulperi, M. N. A. Amal, M. T. Yusof, M. Z. Saad, and M. Y. I. Salwany, Prevalence, Antimicrobial Susceptibility and Plasmid Profiling of Vibrio spp. Isolated from Cultured Groupers in Peninsular Malaysia. BMC Microbiology, 2019. 19: p. 251. 